\title{
The maspin expression in canine mammary tumors: An immunohistochemical and molecular study ${ }^{1}$
}

\author{
Debora A.P.C. Zuccari2 ${ }^{\star}$, Rodrigo Castro ${ }^{3}$, Arieli F. Gavioli4, Ulises M. \\ Mancini ${ }^{5}$, Eloisa H. Tajara ${ }^{5}$, Cibelli S. Frade ${ }^{3}$, Luana R. Pivaro ${ }^{3}$, Juliana \\ Carmona-Raphe $^{5}$, Ana Carolina B. Terziann ${ }^{6}$, Camila M. Ruiz ${ }^{7}$, Eny M. Goloni \\ Bertollo ${ }^{3}$ and Érika C. Pavarino-Bertelli ${ }^{3}$
}

\begin{abstract}
Zuccari D.A.P.C, Castro R., Gavioli A.F., Mancini U.M., Frade C.S., Pivaro L.R., Carmona-Raphe J., Terzian A.C.B., Ruiz C.M., Goloni-Bertollo E.M., Pavarino-Bertelli E.C. \& Tajara E.H. 2009. The maspin expression in canine mammary tumors: An immunohistochemical and molecular study. Pesquisa Veterinária Brasileira 29(2):167173. Centro Regional de Bioterismo, Faculdade de Medicina de São José do Rio Preto, Av. Brigadeiro Faria Lima 5416, São José do Rio Preto, SP 15090-000, Brazil. E-mail: debora.zuccari@famerp.br

The serpin maspin, a tumor suppressor in breast cancer was described as an inhibitor of cell migration and inducer of cell adhesion between the basement membrane and extracellular matrix resulting in inhibition of tumor metastasis. In contrast, overexpression of maspin is correlated with poor prognosis in other types of cancer. Little is known about expression, regulation and function of maspin in canine mammary tumors. It was demonstrated in this study, a loss of maspin expression in malignant canine mammary cells compared with a pool of normal canine mammary tissue, analyzed by quantitative real-time PCR; weak maspin expression in malignant canine mammary tumors were observed by immunohistochemistry. It was also demonstrated that a correlation with nuclear maspin expression and a good prognosis. It is suggested that maspin could be used as a prognostic marker in canine mammary neoplasia.
\end{abstract}

INDEX TERMS: Maspin, canine mammary tumor, immunohistochemistry, molecular biology, prognosis.

RESUMO.- [A expressão do maspin nos tumores mamários caninos: um estudo imuno-histoquímico e molecular.] O serpin maspin, um supressor tumoral no câncer de mama foi descrito como inibidor de migração celular e indutor de adesão celular entre a membrana basal

\footnotetext{
${ }^{1}$ Received on August 11, 2008.

Accepted for publication on January 25, 2009.

${ }^{2}$ Centro Regional de Bioterismo, Faculdade de Medicina de São José do Rio Preto (FAMERP), Av. Brig. Faria Lima 5416, São José do Rio Preto, SP 15090-000, Brazil. *Corresponding author: debora.zuccari@famerp.br

${ }^{3}$ Unidade de Pesquisa em Genética e Biologia Molecular, FAMERP, São José do Rio Preto, SP.

${ }^{4}$ Laboratório de Patologia Animal, Universidade Estadual Paulista "Júlio de Mesquita Filho", Rua Clóvis Pestana 793, Araçatuba, SP 16050-680, Brazil.

${ }^{5}$ Laboratório de Bioinformática, FAMERP, São José do Rio Preto, SP

${ }^{6}$ Laboratório de Pesquisa em Virologia, FAMERP, São José do Rio Preto, SP.

${ }^{7}$ Laboratório de Patologia e Biologia Molecular Veterinária, Rua Coronel Manuel de Moraes 146, Jardim Brasil, Campinas, SP 13073-022, Brazil.
}

e a matriz extracelular resultando na inibição da metástase tumoral. Por outro lado, a alta expressão do maspin está relacionada com um mau prognóstico em outros tipos de câncer. Pouco se sabe sobre a expressão, regulação e função do maspin nos tumores mamários caninos. Neste estudo, foi demonstrada uma perda da expressão de maspin nas células mamárias malignas de cães quando comparadas com um pool de tecido mamário normal de cães, analisado por PCR quantitativa em tempo real. Houve uma expressão fraca maspin em preparações de tumores mamários malignos observadas por imuno-histoquímica. Também foi verificado que a expressão nuclear do maspin em tumores mamários caninos está relacionada a um bom prognóstico. Assim, o maspin pode ser utilizado como um marcador prognóstico nas neoplasias mamárias em cães.

TERMOS DE INDEXAÇÃO: Maspin, tumor mamário canino, imuno-histoquímica, biologia molecular, prognóstico. 


\section{INTRODUCTION}

Maspin is an unique serine proteinase inhibitor that has tumor suppressor activity (Shi et al. 2001, Lee et al. 2006). It is structurally a member of the serpine (serine protease inhibitors) superfamily (El-Wahed 2005). Maspin was initially identified in normal mammary gland in myoepithelial cells, and later in breast cancer cells (Khalkhali-Ellis \& Hendrix 2003), hence its name (mammary serine protease inhibitor). Little is known about physiological role and the mechanism of action for maspin. Experimental evidences showed that maspin suppresses tumor growth, angiogenesis, invasion and metastasis (Streuli 2002, Marioni et al. 2008).

Mammary neoplasms are the most common tumors in female dogs, and are responsible for approximately $52 \%$ of all neoplasms affecting this animal species (MacEwen 1990, Sørenmo 1998, Zuccari 2001). It is known that there are numerous indicators of breast cancer prognosis, including the type, size and classification of the tumor, and involvement of surrounding lymphoid tissue. These indicators may be used individually or in combinations to define the prognosis and outcome of the disease (Perez et al. 2000, Van't Veer et al. 2002). Moreover, although this is a more complex procedure, the evaluation of the expression of one or more prognosis markers may be a useful and conclusive diagnostic tool (Thomas \& Berner 2000).

Maspin appears to be a very sensitive marker of normal and neoplastic myoepithelium of the canine mammary gland whose identification in different cell types of complex and mixed histologic types of tumors (Espinosa de los Monteros et al. 2005) but little is known about its role in canine mammary tumors.

Numerous studies suggest that maspin cancer suppressive function results in inhibition of invasiveness and metastasis (Latha et al. 2005, Sopel et al. 2005). Maspin is a multifaceted protein, regulating tumor cell homeostasis through inhibition of cell growth, motility and invasion (Beltran et al. 2007). Data concerning the role and clinical significance of maspin in human breast cancer are equivocal. Some experiments demonstrate an inverse correlation between the decrease in maspin expression and the increase in breast cancer malignancy and poor clinical course of the disease (Maass et al. 2001) while other suggest that strong maspin expression is a poor prognostic factor in breast cancer (Umekita et al. 2002). There is only one article evaluating maspin in relation to canine mammary tumors (Espinosa de los Monteros et al. 2005).

Maspin expression has always regarded to be limited to the cellular cytoplasm. However the presence of maspin in both the nucleus and cytoplasm has been shown by using cell fractions and Western blotting techniques (Pemberton et al. 1997) and immunohistochemistry (IHC) (Chu et al. 1999, Lee et al. 2006). The current study evaluates the maspin expression in canine mammary neoplasms and its prognostic value.

\section{MATERIALS AND METHODS}

\section{Specimens}

Tumor fragments were surgically removed from 56 female dogs, both purebreds and mongrels with ages of 2-17 years (mean 10 years). For each animal two fragments were collected. For the molecular procedure, the sample was immediately frozen after surgery and for the IHC procedure, it was fixed in $10 \%$ buffered formalin solution. After dehydration and embedment in paraffin wax, 3Pm sections were obtained from each block. One section was stained with hematoxylin and eosin and selected representative sections used for in IHC.

The histopathological classification of tumor type was based on the World Health Organization classification system for canine mammary tumors (WHO 2007). By using a previously established histological grading system for human breast carcinomas and an evaluation of cellular malignancy criteria, three degrees of histological malignancy were identified in canine mammary tumors (Marioni et al. 2008). The dogs were followed-up for 18 months. Metastasis to lymph nodes and overall survival (OS) were also evaluated (Table 1). Normal mammary gland tissue from 10 female dogs euthanized at the Zoonosis Control Center were used as a pool control in the molecular study to compare with the tumoral cases. The females had the same fenotypic features as the group studied have.

\section{Maspin immunostaining}

The monoclonal antibody used was a mouse monoclonal anti-human maspin (clone G167-70 Novocastra, Novocastra Laboratories, Newcastle Upon Tyne, United Kingdom) diluted 1:50 in bovine serum albumin (BSA Sigma-Aldrich, SigmaAldrich, St Louis, USA). Sections 3zm thick were cut from at least one representative block of each case and collected onto silanized slides for adhesion of tissue sections. The slides were then deparaffined, rehydrated in graded alcohols, and incubated with $3 \%$ hydrogen peroxidase for 30 minutes to block endogenous peroxidase activity. Induced antigen retrieval in a

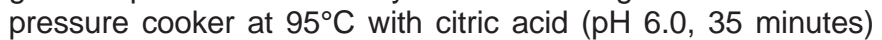
was used. After cooling down, the slides were covered with bovine serum albumin for 30 minutes before incubation with the primary antibody anti-human maspin for two hours at room temperature, and the avidin-biotin-peroxidase complex (ABC Erviegas, Erviegas, São Paulo, Brazil) for one hour. The chromogen, 3,3' diaminobenzidine tetrahydrochloride $0.5 \%$ (Sigma-Aldrich, St Louis, USA) diluted in phosphate-buffered saline was applied to the slides for $2-5$ minutes at $20-22^{\circ} \mathrm{C}$. Slides were counterstained with Harris's Hematoxylin. Negative controls were obtained by omitting the primary antibody, whereas normal mammary gland tissue served as an internal positive control in every assay. Expression of the marker was verified in accordance with graduation of expression (Allred et al. 1998).

\section{Evaluation of immunohistochemical data}

Multiple fields of each slide were examined and demarcation was indicated by the presence of distinct brown nuclear or cytoplasmatic staining. The immunostaining was evaluated separately, and results were based on the consensus of two observers. The amount of positive cells was determined as a percentage of the total number of cells observed in each slide. Thus, the semiquantitative scoring (SQS) was (-) when none of the cells were stained, $(+)$ when the stained was focal, $(++)$ when positive cells represented less than $25 \%$ of cells observed, (+++) when positive cells represented $25 \%-50 \%$ of cells observed, and $(++++)$ when more than $50 \%$ of the cells observed were 
positive. Additionally, nuclear and cytoplasmatic expressions were differentiated.

\section{Quantitative polymerase chain reaction}

A quantitative real-time polymerase chain reaction (PCR) was performed in triplicates using an ABI Prism 7500 Sequence
Detection System Applied Biosystems (Applied Biosystems, Foster City, EUA). Briefly, the reactions were performed in 20PI with 10il of Power SYBR Green PCR Master Mix (Applied Biosystems, Foster City, USA), 250nM of each primer and 10ng cDNA. The PCR conditions were $50^{\circ} \mathrm{C}$ for $2 \mathrm{~min}, 95^{\circ} \mathrm{C}$ for $10 \mathrm{~min}$ followed by 35 cycles of $95^{\circ}$ for $15 \mathrm{sec}, 60^{\circ} \mathrm{C}$ for $1 \mathrm{~min}$. Following

Table 1. Immunohistochemistry, molecular expression of maspin, histopathological diagnosis, outcome of the disease and disease free interval of mammary tumors from $\mathbf{5 6}$ dogs

\begin{tabular}{|c|c|c|c|c|c|c|}
\hline Sample & $\mathrm{HIC}^{\mathrm{a}}$ & Immunostaining & $\mathrm{PCR}^{\mathrm{b}}$ & Histopathology & Outcome & DFIC \\
\hline 1 & $0.2^{\mathrm{d}}$ focal & Cytoplasmic & $\mathrm{O}^{\mathrm{e}}$ & Malignant mixed tumor & Died-euthanasia & $<6$ \\
\hline 2 & 0.8 focal & Cytoplasmic & $\mathrm{O}$ & Simple carcinoma & Died-met ${ }^{f}$ & $6-18$ \\
\hline 3 & Negative & Negative & $\mathrm{O}$ & Malignant mixed tumor & Died-met & $<6$ \\
\hline 4 & 6.9 focal & Cytoplasmic & $\mathrm{O}$ & Tubulopapillary carcinoma & Survived & $>18$ \\
\hline 5 & 0.2 focal & Cytoplasmic & $\mathrm{O}$ & Solid carcinoma & Died-met & $6-18$ \\
\hline 6 & 25 moderate & Cytoplasmic & $\mathrm{O}$ & Complex carcinoma & Survived-rec ${ }^{g}$ & $>18$ \\
\hline 7 & Negative & Negative & $\mathrm{O}$ & Solid carcinoma & Died-rec & $>18$ \\
\hline 8 & Negative & Negative & $\mathrm{O}$ & Fibrosarcoma & Survived & $>18$ \\
\hline 9 & 56.3 strong & Cytoplasmic & $U^{h}$ & Tubulopapillary carcinoma & Survived & $>18$ \\
\hline 10 & 0.4 focal & Nuclear & U & Malignant mixed tumor & Died-met & $<6$ \\
\hline 11 & 12.2 weak & Cytoplasmic & $U$ & Solid carcinoma & Died-met & $>6$ \\
\hline 12 & 3.7 focal & Nuclear & U & Solid carcinoma & Died & $>18$ \\
\hline 13 & 0.1 focal & Cytoplasmic & $\mathrm{O}$ & Malignant mixed tumor & Survived & $>18$ \\
\hline 14 & Negative & Negative & $U$ & Complex carcinoma & Alive & $>18$ \\
\hline 15 & 16.7 weak & Cytoplasmic & $U$ & Solid carcinoma & Died-met & $>18$ \\
\hline 16 & Negative & Negative & $U$ & Solid carcinoma & Died-met & $6-18$ \\
\hline 17 & Negative & Negative & $U$ & Tubulopapillary carcinoma & Survived & $>18$ \\
\hline 18 & Negative & Negative & U & Spindle cell sarcoma & Survived & $>18$ \\
\hline 19 & Negative & Negative & $U$ & Fibrosarcoma & Survived & $>18$ \\
\hline 20 & 50.5 strong & Nuclear & U & Tubulopapillary carcinoma & Died & $6-18$ \\
\hline 21 & 0.2 focal & Nuclear & $\mathrm{O}$ & Solid carcinoma & Survived & $>18$ \\
\hline 22 & 7.5 focal & Nuclear & $U$ & Benign mixed tumor & Survived & $>18$ \\
\hline 23 & 42.6 moderate & Nuclear & $U$ & Tubulopapillary carcinoma & Survived & $>18$ \\
\hline 24 & 33.9 moderate & Cytoplasmic & $U$ & Solid carcinoma & Died-rec & $>6$ \\
\hline 25 & Negative & Negative & U & Benign mixed tumor & Survived & $>18$ \\
\hline 26 & 0.7 focal & Cytoplasmic & U & Solid carcinoma & Died & 0 \\
\hline 27 & 0.2 focal & Cytoplasmic & U & Tubulopapillary carcinoma & Survived & $>18$ \\
\hline 28 & 48.5 moderate & Nuclear & U & Tubulopapillary carcinoma & Died-rec & $>18$ \\
\hline 29 & 48.2 moderate & Nuclear & U & Complex carcinoma & Survived & $>18$ \\
\hline 30 & 16.4 weak & Cytoplasmic & U & Complex carcinoma & Died-met & $>18$ \\
\hline 31 & 72.5 strong & Nuclear & U & Tubulopapillary carcinoma & Survived -rec & $>18$ \\
\hline 32 & 52.8 strong & Cytoplasmic & U & Tubulopapillary carcinoma & Died-rec & $>6$ \\
\hline 33 & 67.5 strong & Nuclear & $\mathrm{U}$ & Solid carcinoma & Survived & $>18$ \\
\hline 34 & 52.9 strong & Nuclear & U & Complex carcinoma & Died-rec & $6-18$ \\
\hline 35 & 32.2 moderate & Cytoplasmic & U & Carcinoma with squdiffi & Died-rec & $>18$ \\
\hline 36 & 38.6 moderate & Nuclear & $U$ & Tubulopapillary carcinoma & Survived & $>18$ \\
\hline 37 & 34.8 moderate & Cytoplasmic & $U$ & Tubulopapillary carcinoma & Survived & $>18$ \\
\hline 38 & 15 weak & Nuclear & $\mathrm{O}$ & Complex carcinoma & Survived & $>18$ \\
\hline 39 & 26.4 moderate & Nuclear & $\mathrm{O}$ & Adenoma & Survived & $>18$ \\
\hline 40 & 54.2 strong & Nuclear & $U$ & Tubulopapillary carcinoma & Died-rec & $>18$ \\
\hline 41 & 34 moderate & Nuclear & $U$ & Malignant mixed tumor & Survived & $>18$ \\
\hline 42 & 15.2 weak & Cytoplasmic & $\mathrm{O}$ & Solid carcinoma & Survived & $>18$ \\
\hline 43 & 26.6 moderate & Nuclear & $\mathrm{O}$ & Complex carcinoma & Survived & $>18$ \\
\hline 44 & 39.1 moderate & Nuclear & $U$ & Tubulopapillary carcinoma & Survived & $>18$ \\
\hline 45 & 26.7 moderate & Cytoplasmic & $U$ & Complex carcinoma & Died-euthanasia & $>6$ \\
\hline 46 & 6.6 focal & Cytoplasmic & $U$ & Tubulopapillary carcinoma & Survived & $>18$ \\
\hline 47 & 1.0 focal & Nuclear & $U$ & Tubulopapillary carcinoma & Survived & $>18$ \\
\hline 48 & 18.5 weak & Nuclear & $U$ & Tubulopapillary carcinoma & Survived & $>18$ \\
\hline 49 & 4.3 focal & Nuclear & $U$ & Simple carcinoma & Survived & $>18$ \\
\hline 50 & Negative & Negative & $\mathrm{O}$ & Solid carcinoma & Survived & $>18$ \\
\hline 51 & Negative & Nuclear & U & Solid carcinoma & Survived & $>18$ \\
\hline 52 & 18.6 weak & Nuclear & $\mathrm{O}$ & Tubulopapillary carcinoma & Survived & $>18$ \\
\hline 53 & Negative & Negative & $U$ & Ductal hyperplasia & Survived & $>18$ \\
\hline 54 & 3.7 focal & Nuclear & $U$ & Malignant mixed tumor & Died-met & $>6$ \\
\hline 55 & 45.5 moderate & Nuclear & $U$ & Tubulopapillary carcinoma & Survived & $>18$ \\
\hline 56 & 32.9 moderate & Cytoplasmic & $U$ & Benign mixed tumor & Survived & $>18$ \\
\hline
\end{tabular}

$\overline{\mathrm{a} \text { Immunohistochemistry, }}{ }^{\mathrm{b}}$ real time-polymerase chain reaction, ${ }^{\mathrm{c}}$ disease free interval (all numbers in this column refer to months; the Dog \# 26 died in the post-surgical period), ${ }^{d}$ percentage of maspin expression in 1,000 cells counted according to Allred et al. (1998), ${ }^{e}$ overexpression, ${ }^{f}$ death with metastasis, ${ }^{9}$ recurrence, ${ }^{h}$ underexpression, i squamous differentiation. 
the PCR, dissociation curve analysis was performed to confirm the desired single gene product: 1 cycle of $95^{\circ} \mathrm{C}$ for $15 \mathrm{sec}, 60^{\circ} \mathrm{C}$ for $1 \mathrm{~min}, 95^{\circ} \mathrm{C}$ for $15 \mathrm{sec}$. Each transcript level was normalized by division with the expression values of the HPRT1 used as internal control. Transcript level was calculated using the $2-\triangle \mathrm{Ct}$ method (Livak \& Schmittgen 2001), where $\triangle$ Ct was the difference between the threshold cycles of a target and the internal controls and $\triangle \triangle \mathrm{Ct}$ was the difference between the average $\triangle \mathrm{Ct}$ of the sample and the average $\triangle \mathrm{Ct}$ of the calibrator sample. The fold difference (relative abundance) was calculated using the formula 2- $\triangle \triangle C T$ and was plotted as means $\pm S D, n=3$ technical replicates. Fold differences of $>3$ were considered to be significant.

All the reactions were done with a negative control and one sample was chosen as the calibrator control for the reactions. Experiments were repeated when the coefficient of variation was higher than $5 \%$. After each reaction, the products were analyzed on a $2 \%$ agarose gel stained with ethidium bromide.

Primers used for amplification were as follows: Maspin sense (5'-GAT TGG TCC ACT GCA AGA GC-3') and antisense (5'GCA TGC TCA TTC TGC TAC CC -3'); and HPRT1, sense (5'TTA TAG TCA AGG GCA TAT CC -3') and antisense (5'- AGC TTG CTG GTG AAA AGG AC -3').

\section{Statistical analysis}

Multivariate logistic regression analyses of prognostic factors were performed. Results were analyzed on the basis of tumor diagnosis and patient outcome, using histological expression of the antibodies by Analysis of dependency (Cordeiro 1987). The differences of means between groups were assessed by the Student's t-test. $\mathrm{P}<0.05$ was considered significant (two tail analysis). All statistical analysis was performed using Microsoft office XP Software (Minitab, version 12.22).

\section{RESULTS}

The histopathologic evaluation of the samples showed a predominance of carcinomas (42 dogs or $75 \%$ ) in the studied group. Five dogs ( $9 \%$ ) had benign tumors and three had sarcomas. In eight cases the neoplasma were classified as mixed malignant tumors. (Table 1).

The tumor types in the carcinoma group in order of decreasing frequency were simple carcinoma in 33 dogs, complex carcinoma in seven dogs and carcinoma with squamous differentiation in one dog. The immunohistochemical analyses of maspin showed an independent distribution of the expression of this protein related to the diagnosis. The tumors considered having the worst prognosis, the carcinomas and sarcomas, had a negative and focal expression (45\% cases with this diagnosis)

In the statistical evaluation there were no significant association with the diagnosis, but with the prognosis $(p=0.003)$. We found that when the expression was moderate and strong, the dogs are still alive and when the expression was weak and focal, the predominance was death (Fig.1). This group showed a low maspin expression when compared with metastasis (two negative, four focal and three weak) in IHC study and 7 (70\%) had gene underexpression in molecular study when compared with the occurrence of metastasis. It was also possible to observe that when the nuclear demarcation is present it is related to moderate or strong expression $(25 \%)(p=0.026)$

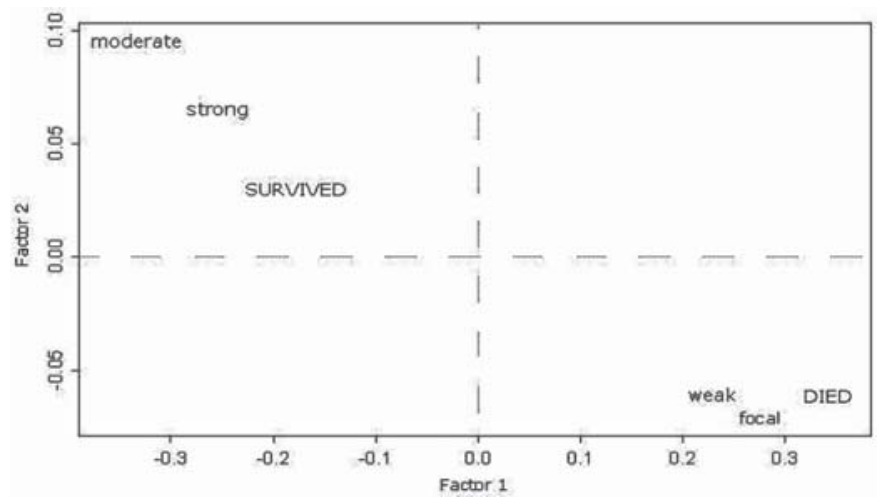

Fig.1. Immunohistochemistry labeling of maspin in canine mammary tumors and its correlation with overall survival time in affected dogs. Analyses of dependency (Cordeiro 1987).
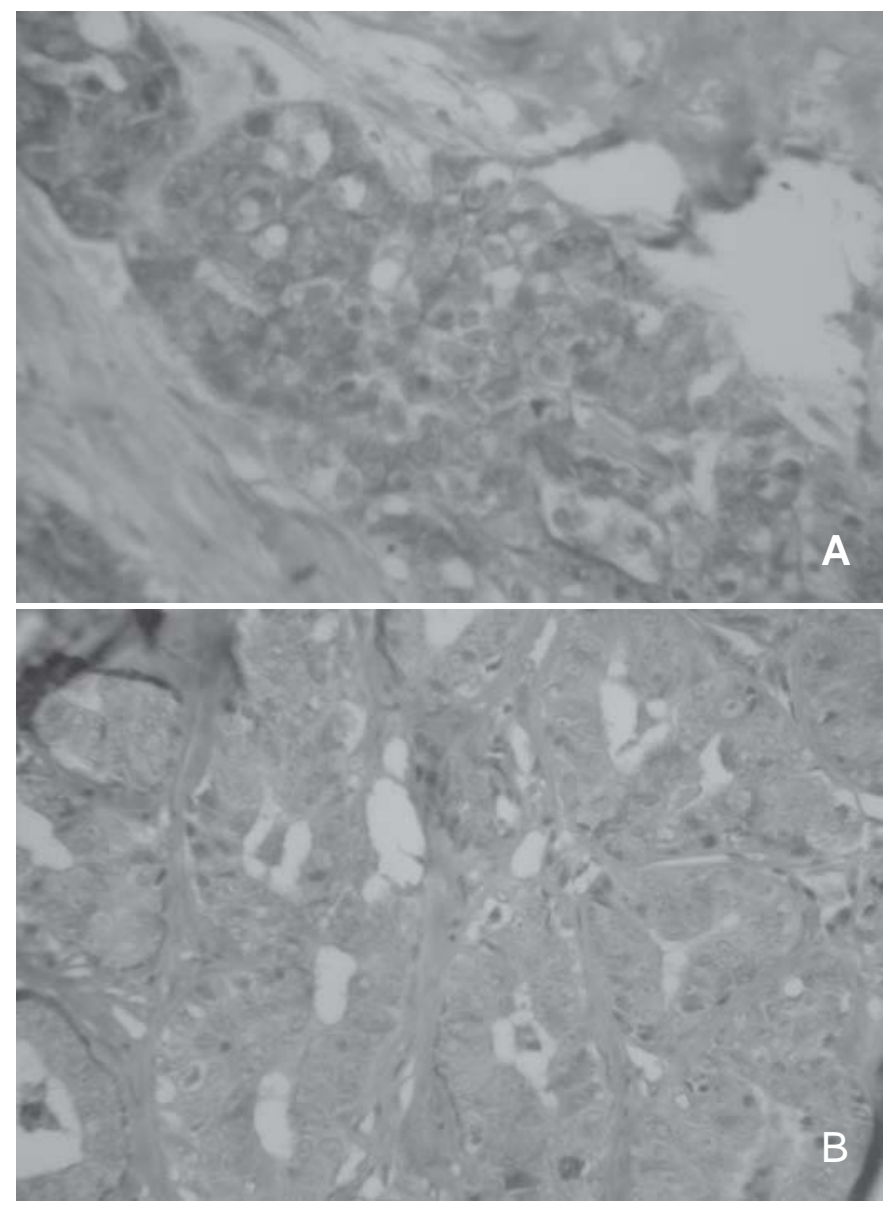

Fig.2. Immunohistochemistry of tubulopapillary carcinomas from Dogs 43 and 32 respectively with predominant nuclear $(\mathbf{A})$ and cytoplasmatic (B) expression of maspin. Notice gold staining of the nucleus in $A$ and bluish gold cytoplasmic staining in B. Mouse monoclonal anti-human maspin, avidinbiotin-peroxidase, diaminobenzidine tetrahydrochloride chromogen, counterstained with Harris hematoxylin, obj.40x.

and with a better prognosis (30.4\%) in the studied cases (Fig.2).

In the molecular study the results showed that in the group of 56 animals, there was gene underexpression in 


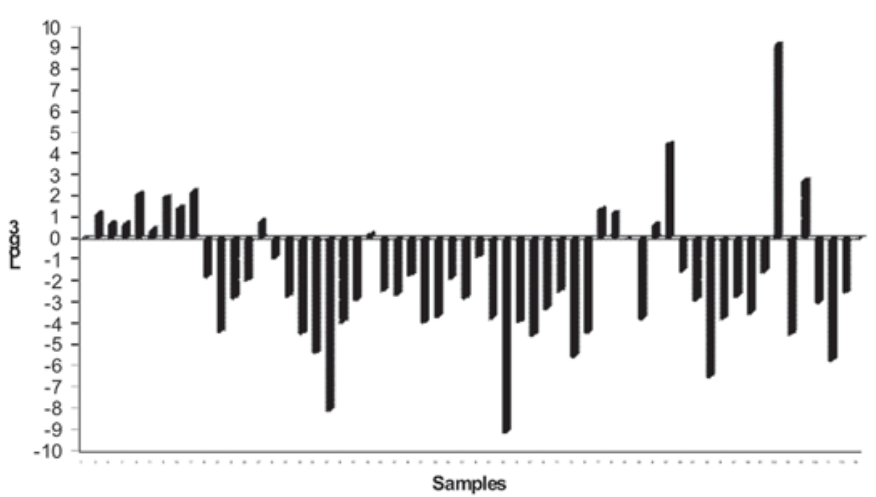

Fig.3. Quantitative gene expression of maspin in tissue samples from canine mammary neoplasms (black bars). The results of a pool of normal canine mammary gland which was plotted as the first bar is equal to zero.

$71.5 \%$ or 40 female dogs. Also, from that 16 animals overexpressed against the normal female pool, only 5 had a bad prognosis and $68.75 \%$ were still alive (Fig.3). A comparison between $\mathrm{IHC}$ and the molecular studies reveal that sixteen tumor cases showed maspin superexpression in the RT-PCR and underexpression in the IHC. On the other hand, tumors from ten dogs presented superexpression in the $\mathrm{IHC}$ and underexpression in RT-PCR.

\section{DISCUSSION AND CONCLUSION}

Proteinases and their inhibitors are known to play important roles in tumor invasion and metastasis. Two classes of proteinases have been extensively studied in breast and other types of cancer: 1) serine proteinase and their inhibitors (plasminogen activator inhibitors) and 2) the metalloproteinases and the tissue inhibitors of metalloproteinases. Serpin (mammary serpin) is a novel proteinase inhibitor related to other inhibitors (Lee et al. 2006).

It has been reported that maspin is expressed in normal human mammary epithelial cells and it is downregulated during the progression of cancer. The serpin maspin has previously been described to have tumorsuppressive activity as it inhibits cell motility, invasion and metastasis of breast cancer cells. Maspin-transfected mammary cancer cell lines had a reduced capacity for tumorigenesis and metastasis even in nude mice (Sheng 2004). In consequence, loss of maspin expression was associated with poor prognosis in breast, prostatic and oral cancer (Hojo et al. 2001, Maass et al. 2001, Zou et al. 2002, Lockett et al. 2006). In this context, maspin expression showed to be in agreement with the consulted literature.

The serine protease inhibitor superfamily (serpins) consists of inhibitory and noninhibitory serpins. Inhibitory serpins use their reactive center loop to trap the target proteinase and inhibit its activity. The noninhibitory serpins have shorter $\mathrm{NH} 2$ and $\mathrm{COOH}$ terminal, and they also lack the classic serpin secretory signal peptide. Recent studies indicate serpins function beyond their serpin properties: they are involved in cell adhesion and play a role in extracellular matrix remodeling. In the past decade, with the expansion of studies on maspin, novel protein-binding partners have been identified and provided insight into the molecular aspects of its regulation and its divergent mechanism of action. More importantly, they have presented new prospects for therapeutic interventions for breast, prostate, and many other cancers (Khalkhali-Ellis 2006). Maspin was first identified as a putative suppressor of metastasis by virtue of its high level of expression in normal mammary epithelial cells as compared to its greatly reduced or absent expression in malignant cells. Due to its structural homology to serine protease inhibitors (serpins), maspin was initially thought to regulate metastasis via inhibition of serine proteases involved in regulating cell-cell and/or cell-extracellular matrix interactions. However, it was later determined that maspin did not inhibit trypsin-like serine proteases, providing compelling evidence that maspin, unlike other serpins, was not a classical serine protease inhibitor (Affara \& Coussens 2007) More recent investigations revealed that maspin regulates metastasis, in part, by altering integrin profiles associated with increased cellular adherence to fibronectin, thus reducing ability of cells to move through fibronectin matrices. Although maspin displays antimetastatic properties during mammary and prostate cancer development, its expression is maintained during ovarian, lung, and pancreatic carcinogenesis, indicating that maspin regulated metastatic potential is tissue specific (Affara \& Coussens 2007). As demonstrated in the current study (Table 1), the metastasis rate related with low maspin expression is in agreement with the data of these cited authors.

Maspin seems to be of ambivalent nature, as positive maspin expression was found in cancer of colon (Bettstetter et al. 2005, Dietmaier et al. 2006) and pancreas (Maass et al. 2001), and higher levels of maspin expression correlated with poor prognosis in some types of breast cancer (Sheng 2004).

Its expression was always regarded to be limited to the cytoplasmatic compartment of the cell. However, it was first demonstrated, by western blotting and IHC (Pemberton et al. 1997), that maspin can be detected in the nucleus of cancer cells. More recently, a few other investigators have documented the presence of nuclear maspin in human breast, ovary, prostate, skin, and pancreatic tumors (Zou et al. 2002, El-Wahed 2005, Marioni et al. 2008). Nuclear immunoreactivity observed with maspin antibodies is now considered specific, but the function and significance of this pattern of expression is unknown. One possible explanation for the detection of signals from both nucleus and cytoplasm with using $\mathrm{IHC}$ is the antigen retrieval technique; this might have exhibited a crossreacting epitope in the nucleus. As our results it was reported that maspin nuclear staining was significantly associated with good prognostic factors, while cytoplasmatic staining was associated with poor prognostic markers (Lee et al. 2006).

During tumor progression was demonstrated the difference between the protein expression and the loss of 
gene expression combining absent Ets and Ap1 transactivation with epigenetic silencing by methylation (Affara \& Coussens 2007). It is now established that maspin is epigenetically regulated, and its tissue-specific expression is closely associated with DNA methylation. Epigenetic changes of maspin expression occur in the 5 ' regulatory region of the maspin gene and involve cytosine methylation, histone deacetylation, and chromatin accessibility. The promoter methylation of the maspin gene leads to gene silencing in cancers, such as breast, thyroid, skin, and colon (Potempa et al. 1994, Maass et al. 2001, KhalkhaliEllis 2006).

On the other hand, to explain the strong staining in underexpressed samples by RT-PCR there are three possible explanations. One is the mutation of the maspin gene, the second is a high intracellular concentration of maspin resulting in auto-inhibition of its activity. The third is that myoepithelial cell differentiation in carcinoma cells could contribute to the more aggressive phenotype. As previously described (Lee et al. 2006) we think that the mutation of the maspin gene causes the loss of normal function of the maspin protein. Therefore, mutational analyses with using maspin-positive samples are needed to resolve this issue.

Studies have indicated that overexpression of maspin in gastric, pancreatic, and ovarian cancers results from promoter $\mathrm{CpG}$ demethylation. This clearly indicates that both methylation and demethylation of maspin promoter could regulate maspin gene expression. Interestingly, pharmacologic approaches for DNA demethylation often fail to activate gene expression, indicating that reexpression of certain genes requires supplementary factors and interacting partners in addition to DNA hypomethylation (Khalkhali-Ellis 2006).

In conclusion, maspin appears to be a very sensitive marker of canine mammary cancer working as a suppressor gene. The relationship between maspin expression in different cellular compartments of canine mammary tumors and the biologic aggressiveness of the disease could be a prognostic tool but its value remains to be elucidated.

Acknowledgments.- To Dr. Lilian Castiglioni for help in the development of the project; to Prof. Dr. Felipe Augusto Ruiz Sueiro, Profa. Dr. Noeme S. Rocha and Prof. Dr. Cicero Meneghetti for their support in reading and analyzing the slides; to Prof. Dr. José Antônio Cordeiro for the statistical analysis of study data; and to Fundação de Amparo à Pesquisa de São Paulo (FAPESP) for funding (Proc.05/51936-0).

\section{REFERENCES}

Affara N.I. \& Coussens L.M. 2007. IKK alpha at the crossroads of inflammation and metastasis. Cell 129(1):25-26.

Allred D.C., Harvey J.M., Berardo M. \& Clark G.M. 1998. Prognostic and predictive factors in breast cancer by immunohistochemical analysis. Modern Pathology 11(2):155-168.

Beltran A., Parikh S., Liu Y., Cuevas B.D., Johnson G.L., Futscher B.W. \& Blancafort P. 2007. Re-activation of a dormant tumor suppressor gene maspin by designed transcription factors. Oncogene 26(19):27912798.
Bettstetter M., Woenckhaus M., Wild P.J., Rümmele P., Blaszyk H., Hartmann A., Hofstädter F. \& Dietmaier W. 2005. Elevated nuclear maspin expression is associated with microsatellite instability and high tumour grade in colorectal cancer. J. Pathol. 205(5):606614.

Chu Y.C., Park I.S., Kim Y.J., Kim J.M., Han H.S., Han J.Y. \& Kim Y.B. 1999. Expression of maspin protein in ductal hyperplasia, intraductal carcinoma and invasive ductal carcinoma of the breast. Korean J. Pathol. 33(8):614-619.

Cordeiro J.A. 1987. Analysis of Dependency. Relatório Técnico no 48/ 87, Instituto de Matemática e Estatística Unicamp, Campinas. 768p.

Dietmaier W., Bettstetter M., Wild P.J., Woenckhaus M., Rümmele P., Hartmann A., Dechant S., Blaszyk H., Pauer A., KlinkhammerSchalke M. \& Hofstädter F. 2006. Nuclear maspin expression is associated with response to adjuvant 5-fluorouracil based chemotherapy in patients with stage III colon cancer. Int. J. Cancer 118(9):2247-2254.

El-Wahed M.M.A. 2005. Expression and subcellular localization of maspin in human ovarian epithelial neoplasms: Correlation with clinicopathologic features. J. Egyptian Natl Cancer Inst. 17(3):173183.

Espinosa de los Monteros A., Millán M.Y., Ramíres G.A., Ordás J., Reymundo C. \& Martín De Las Mulas J. 2005. Expression of maspin in mammary gland tumors of the dog. Vet. Pathol. 42(3):250-257.

Hojo T., Akiyama Y., Nagasaki K., Maruyama K., Kikuchi K., Ikeda T., Kitajima M. \& Yamaguchi K. 2001. Association of maspin expression with the malignancy grade and tumor vascularization in breast cancer tissues. Cancer Lett. 171(1):103-110.

Khalkhali-Ellis Z. 2006. Maspin: The new frontier. Clin. Cancer Res. 12(24):7279-7283.

Khalkhali-Ellis Z. \& Hendrix M.J.C. 2003. Nitric oxide regulation of maspin expression in normal mammary epithelial and breast cancer cells. Am. J. Pathol. 162(5):1411-1417.

Latha K., Zhang W., Cella N., Shi H.Y. \& Zhang M. 2005. Maspin mediates increased tumor cell apoptosis upon induction of the mitochondrial permeability transition. Molec. Cell. Biol. 25(5):17371748.

Lee M.J., Suh C.H. \& Li Z.H. 2006. Clinicopathological significance of maspin expression in brest cancer. J. Korean Med. Sci. 21(2):309314.

Livak K.J. \& Schmittgen T.D. 2001. Analysis of relative gene expression data using real-time quantitative PCR and the 2(-Delta Delta C[T]). Methods 25(4):402-408.

Lockett J., Yin S., Li X., Meng Y. \& Sheng S. 2006. Tumor suppressive maspin and epithelial homeostasis. J. Cell Biochem. 97(4):651-660.

Maass N., Hojo T., Rosel F., Ikeda T., Jonat W. \& Nagasaki K. 2001. Downregulation of the tumor suppressor gene maspin in breast carcinoma is associated with a higher risk of distant metastasis. Clin. Biochem. 34(4):303-307.

MacEwen E.G. 1990. Spontaneous tumors in dogs and cats: Models for the study of cancer biology and treatment. Cancer and Metastases Rev. 9(1):125-136.

Marioni G., Gaio E., Giacomelli L., Bertolin A., D’Alessandro E., Stramare R., Facco E., Staffieri A. \& Blandamura S. 2008. Maspin subcellular localization and expression in oral cavity squamous cell carcinoma. J. Eur. Arch. Oto-Rhino-Laryngol. 265(1):97-104.

Pemberton P.A., Tipton A.R., Pavloff N., Smith J., Erickson J.R., Mouchabeck Z.M. \& Kiefer M.C. 1997. Maspin is an intracellular serpin that partitions into secretory vesicles and is present at the cell surface. J. Histochem. Cytochem. 45:1697-1706.

Perez A.M.D.M., Peña L., Del Castilho N. \& Nieto A.L. 2000. Factors influencing the incidence and prognosis of canine mammary tumours. Department of Animal Pathology II, Veterinary School, Complutense University, Madrid, Spain. Small Anim. Pract. 41(10):476. 
Potempa J., Korzus E. \& Travis J. 1994. The serpin superfamily of proteinase inhibitors: structure, function, and regulation. J. Biol. Chemistry 269(23):15957-60.

Sheng S. 2004. The promise and challenge toward the clinical application of maspin in cancer. Front. Biosci. 9:2733-2745.

Shi H.Y., Zhang W., Liang R., Abraham S., Kittrell F.S., Medina D. \& Zhang M. 2001. Blocking tumor growth, invasion and metastasis by maspin in a syngeneic breast cancer model. Cancer Res. 61(18):6945-6951.

Sopel M., Kasprzyk I. \& Berdowska I. 2005. Maspin and c-erbB-2 expression in correlation with microvessel density in invasive ductal breast cancer. Folia Histochem Cytobiol 43(2):109-116.

Sørenmo K. 1998. An update on canine mammary gland tumors. Proc. ACVIM Forum 16:387-388.

Streuli C.H. 2002. Maspin is a tumour suppressor that inhibits breast cancer tumour metastasis in vivo. Breast Cancer Res. 4(4):137-140.

Thomas E. \& Berner G. 2000. Prognostic and predictive implications of HER2 status for breast cancer patients. Eur. J. Oncol. Nurs. 4:10-17.
Umekita Y., Ohi Y., Sagara Y. \& Yoshida H. 2002. Expression of maspin predicts poor prognosis in breast cancer patients. Int. J. Cancer 100(4):452-455.

Van't Veer L.J., Dai H., Van de Vijver M.J., He Y.D., Hart A.A., Mao M., Peterse H.L., Van der Kooy K., Marton M.J., Witteveen A.T., Schreiber G.J., Kerkhoven R.M., Roberts C., Linsley P.S., Bernards R. \& Friend S.H. 2002. Gene expression profiling predicts clinical outcome of breast cancer. Nature 415:530-536.

WHO (World Health Organization). 2007. Classification system for canine mammary tumors. http://www.who.int/en/.

Zou Z., Zhang W., Young D., Gleave M.G., Rennie P., Connell T., Connelly R., Moul J., Srivastava S. \& Sesterhenn I. 2002. Maspin expression profile in human prostate cancer and in vitro induction of maspin expression by androgen ablation. Clin. Cancer Res. 8(5):1172-1177.

Zuccari D.A.P.C. 2001. Estudo imunocitoquímico de marcadores diagnósticos e prognósticos em neoplasias mamárias caninas. Tese de Doutorado em Clínica Médica Veterinária, Faculdade de Ciências Agrárias e Veterinárias, Unesp, Jaboticabal, SP. 92p. 